\title{
Mechanical properties and total hydroxycinnamic derivative release of starch/glycerol/Melissa officinalis extract films
}

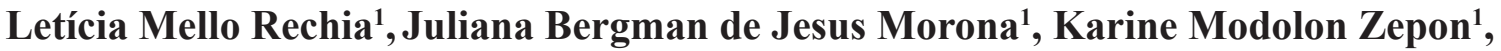 \\ Valdir Soldi², Luiz Alberto Kanis ${ }^{1, *}$
}

${ }^{1}$ TECFARMA, University of Southern Santa Catarina, Tubarão, ${ }^{2}$ POLIMAT, Federal University of Santa Catarina

\begin{abstract}
The aim of this study was to investigate the mechanical properties of starch/glycerol/Melissa officinalis, a topical drug delivery system for labial herpes treatment. Four films were prepared with different concentrations of starch, glycerol, and Melissa officinalis extract. The results revealed that increasing the glycerol concentration in the film reduced elasticity modulus and tensile strength, exhibiting a plasticizing effect. The increase in free volume resulted in increased release of hydroxycinnamic derivatives expressed as rosmarinic acid.
\end{abstract}

Uniterms: Drugs/delivery system. Glycerol. Melissa officinalis. Herpes/treatment. Polymeric film. Starch.

\begin{abstract}
O objetivo deste trabalho foi estudar as propriedades mecânicas e o mecanismo de liberação de um sistema tópico de liberação prolongada para o tratamento do Herpes labial a partir de filmes de amido/glicerol/ extrato de Melissa officinalis, planta com comprovada atividade antiviral. Foram obtidos quatro filmes poliméricos com diferentes concentrações de amido, glicerol e extrato de Melissa officinalis os quais foram caracterizados mecanicamente e determinado o perfil de liberação de derivados hidroxicinâmicos. Os resultados demonstraram que o aumento da concentração de glicerol no filme produz uma redução no módulo de elasticidade e na tensão de deformação como conseqüência do efeito plastificante. $\mathrm{O}$ aumento no volume livre do polímero resultou em aumento da liberação dos derivados hidroxicinâmicos expressos como ácido rosmarínico.
\end{abstract}

Unitermos: Fármacos/sitemas de liberação prolongada. Glicerol. Melissa officinalis. Herpes/tratamento. Filme polimérico. Amido.

\section{INTRODUCTION}

Melissa officinalis L. belongs to the Lamiaceae family. It exhibits many pharmacological activities, including antiviral activity against simple viral herpes type I (HSV-I) and type II (HSV-2). This activity is attributed to chemical constituents, such as rosmarinic acid, caffeic acid, chlorogenic acid, and ferulic acid, which inhibit viral DNA and RNA replication (Allahverdiyev et al., 2004; Jassim, Naji, 2003; British Herbal Pharmacopoeia, 1996; Dimitrova, Dimov, Manaloval, 1993). Moreover, results suggest that constituents of Melissa officinalis extract interact with structures of the virion envelope during the extracellular

\footnotetext{
*Correspondence: L. A. Kanis. Curso de Farmácia - TECFARMA/UNISUL. Av José Acácio Moreira 787, Caixa Postal 307 - 88704-90 - Tubarão - SC, Brasil. E-mail: luiz.kanis@unisul.br
}

phase which are necessary for adsorption or entry into host cells, displaying the highest antiviral activity in vitro against HSV-1 and HSV-2 (inhibitory concentrations of $0.025 \mu \mathrm{g} / \mathrm{mL}$ and $0.027 \mu \mathrm{g} / \mathrm{mL}$ respectively) (Nolkemper et al., 2006).

Due to this activity, proven in clinical trials carried out in vivo and in vitro both in Europe and the USA, Melissa officinalis L. extract has been incorporated into creams for topical treatment of lesions caused by viral herpes (Gaby, 2006; WHO, 2004; Koytchev, Alken, Dundarov, 1999; ESCOP, 1996; Tyler, 1994)

The evolution in the polymeric area fostered the development of new pharmaceutical drug delivery systems, which can maintain the active principle in the target site for a longer period, for example through use of bioadhesive gels and transdermic films. Polymeric films have a number of advantages for chronic treatment, because they typi- 
cally promote gradual and prolonged release of the active principles, leading to better patient adherence to treatment (Freire et al., 2009; Vila Jato, 1995; Veiga, 1988).

Starches are useful natural polymers for numerous food and pharmaceutical applications due to their excellent biodegradability, low production cost and obtainment from renewable resources (Krogars et al., 2003; Fama et al. 2005; Bastida et al., 2005). The application of starch to obtain films is attributed to chemical, physical and functional properties of amylose. The amylose molecules in solution are arranged in parallel, forming hydrogen bonds among adjacent starch chains, reducing polymer water affinity and favoring the obtainment of opaque gels and reduced flexibility films (Lu, 2009; Shimazu, 2007; Jansson, Thuvander, 2004; Soest, Knooren, 1997). The mechanical properties of starch films can be changed by addition of plasticizing agents. Glycerol and sorbitol are the main starch film plasticizers used, given their ability to increase chain mobility as a result of film flexibility (Yu, 2008), a characteristic which favors biomedical applications.

Hydroethanolic extracts from plants such as Melissa officinalis L. can precipitate their constituents when incorporated in polymer solution of solvents such as ketone or chloroform. On one hand, this behavior impossibility uses acrylate derivatives such as Eudragit or vinyl acetate copolymers for the development of polymeric films with plants extracts. On the other hand, hydrophilic polymers such as starch, gelified in water at temperatures above 80 ${ }^{\circ} \mathrm{C}$, which leads to the incorporation of hydroethanolic extracts and produces a good film with optimal appearance and mechanical properties (Larotonda et al. 2004; Fama, et al., 2005).

The topical treatment of labial herpes needs several daily applications, which can cause discomfort for patients. Further research on extended drug release systems is crucial. The aim of this study was to investigate the mechanical properties of Melissa officinalis extract (MOE) and hydroxycinnamic derivative release from polymeric starch/glycerol film.

\section{MATERIAL AND METHODS}

\section{Material}

Melissa officinalis L. hydroalcoholic extract (MOE) (Sanrisil S.A., Brasil); unmodified corn starch containing approx. 73\% amylopectin and 27\% amylose (Sigma Aldrich, Germany); Glycerol (Natural Pharma S.A., Brasil). Rosmarinic acid standard (Chromadex S.A., USA); sodium hydroxide (Nuclear, Brasil); sodium Nitrite, (Nu- clear, Brasil); sodium molybdate (Nuclear S.A, Brasil); Hydrochloric acid (Nuclear S.A, Brasil).

\section{Dry matter from Melissa officinalis extract}

Extract samples of $15 \mathrm{~g}$ were placed on a foil plate and dried until a constant weight at $105^{\circ} \mathrm{C}$. The dry residue (DR) was calculated using Equation 1.

DR $\%=$ Final weight $(\mathrm{g}) \times 100 /$ Initial weight $(\mathrm{g})$

\section{Total hydroxycinnamic derivatives assay expressed as rosmarinic acid (THD)}

The total hydroxycinnamic derivatives in the MOE were assayed by the British Pharmacopoeia method (2004). The calibration curve from the rosmarinic acid standard solution was obtained for the range $5 \mu \mathrm{g} / \mathrm{mL}$ to $25 \mu \mathrm{g} / \mathrm{mL}$ at $505 \mathrm{~nm}$. The stock solution was prepared at a concentration of $100 \mu \mathrm{g} / \mathrm{mL}$ in methanol. From the stock solution, five concentrations were diluted with water $(5$, 10, 15, 20, $25 \mu \mathrm{g} / \mathrm{mL})$. A Hitachi 2010 spectrophotometer was used for absorbance measurements. All the concentrations were measured in triplicate. Origin 7.0 was used for statistical checking of linearity correlation coefficient (r).

\section{Corn starch/glycerol/Melissa officinalis extract film preparation}

Blends of starch/glycerol/MOE (90/0/10; 80/10/10; $70 / 20 / 10$ and 60/30/10) were used to prepare films by the solvent casting method with total weight of $1 \mathrm{~g}$. The quantity of MOE added to the film was calculated from dried matter using Eq. 2.

$$
\mathrm{V}_{\mathrm{e}}=100 \cdot \mathrm{m}_{\mathrm{f}} / \mathrm{DR}
$$

Where, $\mathrm{V}_{\mathrm{e}}=$ MOE volume added to obtain the films $(\mathrm{mL}) ; \mathrm{m}_{\mathrm{f}}=$ weight corresponding to $10 \%$ of total film weight $(\mathrm{g})$; DR $=$ dried residue $(\%)$.

The corn starch was diluted in water at $85^{\circ} \mathrm{C}$ until gelatinized with constant agitation for $2 \mathrm{~h}$. The homogeneous solution was cooled at room temperature and glycerol and MOE were added. The polymer solution was poured into a Petri dish (Teflon) $\left(165.0 \mathrm{~cm}^{2}\right)$ and the solvent was evaporated at a temperature range of $20-24{ }^{\circ} \mathrm{C}$ for one week. After drying, the films were stored in a dessicator under vacuum until analysis. The average film thickness values were determined after measurements at 
different points across the film using a micrometer (Mytotoyo, Japan).

\section{Tensile strength and percentage of elongation}

Tensile tests were performed at $25 \pm 2{ }^{\circ} \mathrm{C}$ and relative humidity of $40 \pm 10 \%$ using an EMIC DL 2000 analyzer (EMIC, Brazil), according to the American Society for Testing and Material (ASTM) protocol D882-95a for thin films. The membranes were kept under vacuum conditions before analysis. Modulus of elasticity $(\lambda)$, tensile strength at rupture and elongation were obtained from the stressstrain curves based on at least six analyses of each sample. Modulus of elasticity $(\lambda)$ was calculated using Eq. 3.

$$
\lambda=\sigma / \varepsilon
$$

Where, $\lambda=$ elastic modulus; $\sigma=$ stress, force causing the deformation divided by the area to which force is applied; $\varepsilon=$ strain, ratio of change caused by stress to the original state of the film.

Percent elongation at breakage was expressed as percentage change of the original specimen length between grips at break, while Tensile strength (MPa) was calculated by dividing maximum load by the cross-sectional area of the film.

\section{Hydroxycinnamic derivatives released from starch/glycerol/MOE films}

The drug release experiments were performed using a horizontal diffusion cell at $37.0 \pm 0.5^{\circ} \mathrm{C}$. The films were clamped with a cellulose acetate membrane $(0.45 \mathrm{um})$ between an acrylic plate and compartment of $7 \mathrm{~mL}$ volume, called the receptor cell (diffusion area $6.8 \mathrm{~cm}^{2}$ ). The deionizated water was placed in the receptor cell and shaken horizontally in a Dubnoff bath (Quimis S.A, Brazil) at the rate of $60 \mathrm{rev} / \mathrm{min}$ to minimize the boundary effect. The total receptor solution volume was removed after predetermined time intervals $(5,10,15,20,30,40,60,90$ and 120 minutes) and replaced with fresh solution at $37^{\circ} \mathrm{C}$. The THD released was determined by UV-Vis spectrometry at $505 \mathrm{~nm}$ (Hitachi 2010), as described in "Total Hydroxycinnamic derivatives assay expressed as rosmarinic acid". Drug release was expressed as $\mathrm{mg} / \mathrm{cm}^{2}$ rate over time. All experiments were performed in triplicate.

\section{Statistical analysis}

Statistical evaluations were performed by analysis of variance (ANOVA) using the statistical package OriginPro 7.0. In all cases the significance level was taken as $\mathrm{P}<0.01$.

\section{RESULTS AND DISCUSSION}

The calibration curve of rosmarinic acid standard solutions $(\mathrm{mg} / \mathrm{mL})$ obtained at $505 \mathrm{~nm}$ showed good linearity and a correlation coefficient ( $r$ ) of 0.99956 , the intercept (a) was -0.04799 and (b) slope of 24.7104. The ANOVA test showed no linearity deviation $(p<0.01)$. The MOE used to obtain the films yielded $0.333 \pm 0.02 \%$ of hydroxycinnamic derivatives expressed as rosmarinic acid and dry residue of $1.57 \pm 0.15 \%$.

\section{Mechanical properties}

The Starch/MOE films obtained by thermal gelatinization showed transparent, homogeneous surfaces without pores or cracks, hardness, and brown color due to MOE. The addition of glycerol allowed the obtention of films with the same characteristics of non-glycerol films, but with the added feature of flexibility.

The use of polymeric membranes for applications in transdermal and topical therapeutic systems depends on their mechanical properties at room temperature. Good elasticity is generally needed. The mechanical parameters obtained in stress-strain curves of the Starch/glycerol/ MOE films are shown in Table I.

TABLE I - Mechanical parameters of Starch/glycerol/MOE films

\begin{tabular}{llll}
\hline $\begin{array}{l}\text { Starch/ } \\
\text { glycerol/ } \\
\text { MOE }(\%)\end{array}$ & $\begin{array}{l}\text { Tensile } \\
\text { strength } \\
\text { (MPa) }\end{array}$ & $\begin{array}{l}\text { Elongation } \\
(\%)\end{array}$ & $\begin{array}{l}\text { Modulus of } \\
\text { elasticity } \\
\text { (MPa) }\end{array}$ \\
\hline $90 / 0 / 10$ & $17.5 \pm 2.0$ & $1.30 \pm 0.11$ & $2120 \pm 460$ \\
$80 / 10 / 10$ & $17.1 \pm 5.0$ & $1.19 \pm 0.48$ & $1711 \pm 380$ \\
$70 / 20 / 10$ & $5.6 \pm 3.2$ & $2.11 \pm 0.32$ & $416 \pm 39$ \\
$60 / 30 / 10$ & $1.2 \pm 0.8$ & $5.6 \pm 1.7$ & $26 \pm 12$ \\
\hline
\end{tabular}

Mean \pm SD of six experiments $(n=6)(p<0.01)$

The tensile testing provided an indication of membrane strength and elasticity, reflected by parameters including tensile strength, modulus of elasticity and elongation at breaking. The behavior of the stress-strain curves showed that glycerol had a plasticizing effect on starch/glycerol/MOE films. No significant differences were observed in any of the parameters evaluated for the films with 0 and $10 \%$ of glycerol content. However, increases in glycerol content of greater than $10 \%$ reduced the tensile strength $(\mathrm{P}<0.01)$ and modulus of elasticity, while significantly increasing $(\mathrm{P}<0.01)$ elongation. Similar behavior has been reported for corn starch films plastici- 
zed with glycerol at $20 \%$ content or more, resulting from glass transition decreasing close to or higher than ambient temperature (Talja, 2008). The starch/glycerol/MOE films containing $30 \%$ glycerol were weaker, more elastic, more flexible and softer. Elongation, for example, increased five-fold when glycerol content rose from 10 to $30.0 \%$. A similar pattern was observed in tensile strength decrease.

Both elongation increase and tensile strength decrease of starch/glycerol/MOE could be due to changes in starch and glycerol content in the film. Starch filmforming capacity is due to amylose, a linear molecule with an extended helical twist (Bastida et al., 2005). The water evaporation of starch solutions during filmforming enhances amylose chain alignment and increases intermolecular attraction between adjacent polymeric chains through hydrogen bonding. This improves film tensile strain and reduces elongation, while the addition of glycerol in starch films causes significant changes in its mechanical properties. Glycerol is compatible with amylose and increases the mobility of polymeric chains by reducing intermolecular attraction and interfering with amylose packing (Lopez, 2008; Bastida et al. 2005; Fama et al. 2005; Robinson, Lee, 1987). The increase in chain mobility improves elongation capacity of starch film but reduces its tensile strength. The glycerol effect on the elongation of starch films observed in this study was less marked than that obtained by other authors, a finding attributed to the heating time of starch gelatinization and the slow drying process used. The starch gelatinization time changes polymeric chain networks while the slow drying process can increase starch crystallinity, decreasing elongation capacity (Paes et al., 2008; Flores et al., 2007; Shimazu et al., 2007).

\section{Hydroxycinnamic derivatives release from starch/ glycerol/MOE films}

The in vitro release test is widely used because of its simplicity and reproducibility. It is known that in vitro drug release does not usually correlate with in vivo release. However, it is possible to show that drug diffusion through the matrix was influenced by plasticizing, polymer composition and drug-polymer interaction (Kanis et al., 2005; Panchagnula, 1997).

Figure 1 shows the in vitro release profiles of total hydroxycinnamic derivatives expressed as rosmarinic acid from the starch/glycerol/MOE films per $\mathrm{cm}^{2}$. The drug release test was carried out for only 120 minutes, because after this time the films became very hydrated and breakable.

Initial drug release from the starch/glycerol/MOE

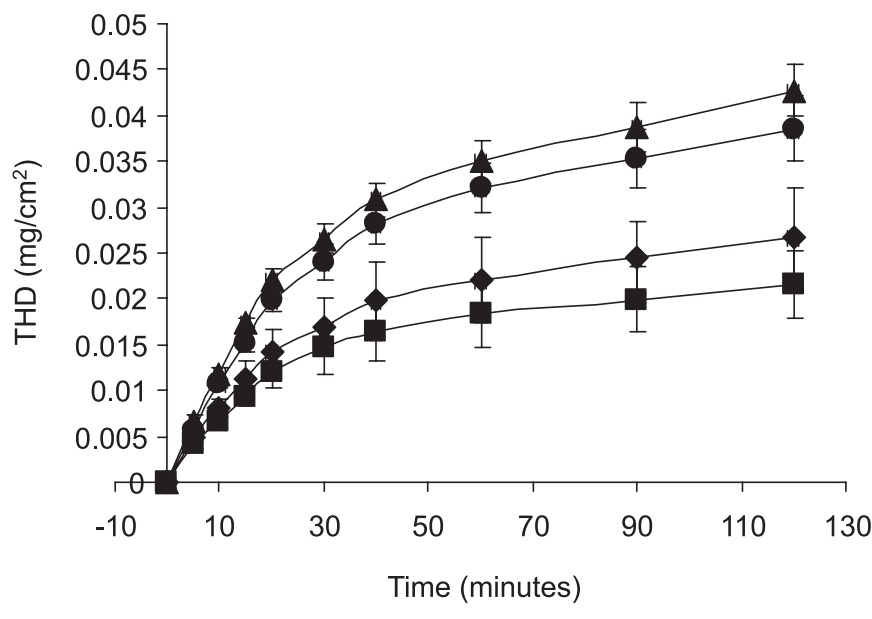

FIGURE 1 - In vitro release profiles of total hydroxycinnamic derivatives expressed as rosmarinic acid from starch/glycerol/ MOE films per $\mathrm{cm}^{2}$ of film. Starch/glycerol/MOE; (•) 90/0/10; (•) 80/10/10; () 70/20/10; (A) 60/30/10.

was fast and the THD was not completely released until 120 minutes. The THD content released from the films increased with higher glycerol content, although no significant differences were observed $(\mathrm{p}<0.01)$ between films with $0 \%$ and $10 \%$ glycerol and between films with $20 \%$ and $30 \%$ glycerol.

In spite of film breakage due to high swelling followed by solubilization in vitro experiments, the starch/ glycerol/MOE films released only around $30 \%$ of their THD content. The topical application of the product on labial herpes lesions may increase film durability and solubility which may consequently increase drug-release time due to reduced wettability at this site.

The release from a planar system having dispersed drug in a homogeneous matrix should follow the relationship:

$$
Q=(D(2 A-C \mathrm{~s}) C \mathrm{~s} t)^{1 / 2}
$$

where $Q$ is the amount of drug released after time $t$ per unit exposed area; $D$ is the diffusivity of the drug in the matrix; $A$ is the initial drug concentration; and $C \mathrm{~s}$ is the drug solubility in the matrix (Higuchi, 1961). Considering that $\mathrm{A} \gg>\mathrm{C}$ s under sink conditions the Eq. 4 was simplified to:

$$
Q=(D 2 A C \mathrm{~s} t)^{1 / 2}
$$

The flux was calculated from the slope of the linear region of the $Q$ versus $t^{1 / 2}$ release profile. The transport mechanism through polymeric systems was described by the Eq. 6 (valid for the first $60 \%$ of fractional release): 
TABLE II - Flux from equation 5, results of calculated number $n$ from equation 6 , correlation coefficient for equation 5 ( $\left.\mathrm{R}_{1}\right)$ and equation $6\left(\mathrm{R}_{2}\right)$, and total hydroxycinnamic derivatives released from the films $(\%)$.

\begin{tabular}{lccccc}
\hline starch/glycerol/MOE & $\mathbf{R}_{\mathbf{1}}$ & Flux $\left(\mathbf{m g} / \mathbf{c m}^{2} \cdot \mathbf{m i n}^{\mathbf{1} / 2}\right) \pm \mathbf{S D}$ & $\boldsymbol{n}$ & $\mathbf{R}_{\mathbf{2}}$ & THD \% \\
\hline $90 / 0 / 10$ & 0.9930 & $0.0031 \pm 1.84 \times 10^{-4}$ & 0.69 & 0.9953 & 19.2 \\
$80 / 10 / 10$ & 0.9959 & $0.0037 \pm 1.66 \times 10^{-4}$ & 0.69 & 0.9964 & 23.5 \\
$70 / 20 / 10$ & 0.9969 & $0.0054 \pm 2.13 \times 10^{-4}$ & 0.74 & 0.9967 & 34.0 \\
$60 / 30 / 10$ & 0.9952 & $0.0059 \pm 2.89 \times 10^{-4}$ & 0.75 & 0.9957 & 37.2 \\
\hline
\end{tabular}

$$
M_{t} / M=b t^{n}
$$

where $M_{t}$ is the amount of the released drug at time $t ; M$ is the overall amount of the drug; $b$ is the constant incorporating structural and geometric characteristics of the controlled release device; and $n$ is the release exponent indicative of the drug release mechanism. For a known geometry system $n=0.5$ indicates Fickian diffusion, $0.5<$ $>1.0$ non-Fickian diffusion, and $n=1.0$ Case II diffusion (Peppas, 1985).

Table II shows the correlation coefficient $\left(\mathrm{R}_{1}\right)$, flux $\left(\mathrm{mg} / \mathrm{cm}^{2} \cdot \mathrm{min}^{1 / 2}\right)$ obtained from Eq. 5, and correlation coefficient $\left(\mathrm{R}_{2}\right)$ and $\mathrm{n}$ values obtained from Eq. 6 and THD released (\%) 120 minutes into the experiment.

The correlation coefficient of the THD release kinetics for all studied films showed good linearity with the Higuchi mathematical model, demonstrating that drug release is diffusion dependent.

Drug release from films with glycerol was generally faster than that of non-glycerol films. The THD flux from film increased from $0.0031 \pm 1.84 \times 10^{-4}$ to $0.0059 \pm 2.89$ $\mathrm{x} 10^{-4} \mathrm{mg} / \mathrm{cm}^{2} \cdot \mathrm{min}^{1 / 2}$ in starch $/ \mathrm{glycerol} / \mathrm{MOE}$ films with $90 / 0 / 10$ to $60 / 30 / 10$, respectively.

It has been reported that the rate of drug release from hydrophilic polymers is governed by polymer structure, molecular weight, and hydration characteristics (Boateng et al., 2009). Upon water contact with starch films, water uptake starts followed by swelling, gel surface formation and consequently drug release by the diffusion mechanism (Yoon et al., 2009, Bialopiotrowicz, 2003). The addition of glycerol provides increased free volume between starch polymeric chains and more hydrophilic active sites in the film due to the glycerol hydroxyl groups which improve film water affinity and aqueous penetration. This results in an increase in hydration velocity and in drug release (Mali, 2005; Michailova, 2001; Galietta et al., 1998).

The transport mechanism (n) obtained from Eq. 4 for all films studied showed anomalous transport, suggesting that the release mechanism of hydroxycinnamic derivatives from starch films was driven by water penetration into the film, which in turn promotes rearrangement of macro- molecular chains and consequently improves diffusion and gel erosion (Mali et al., 2005). Moreover, glycerol content did not alter the mechanism of THD release from starch films.

\section{CONCLUSION}

Increased glycerol content in the films improved elasticity characteristics, a feature important for topical drug delivery system development which can improve the flux of hydroxycinnamic derivatives. The drug release mechanism is anomalous and did not change with the addition of glycerol into the starch matrix. The results showed the potential topical use of these films for treatment of labial herpes.

\section{REFERENCES}

ALLAHVERDIYEV, A.; DURAN, N.; OZGUVEN, M.; KOLTAS, S. Antiviral activity of the volatile oils of Melissa officinalis L. against Herpes simplex virus type-2. Phytomedicine, v.11, p.657-661, 2004.

BASTIDA, C.A.R; PÉREZ, L.A.B; GARCYA, M.A.; MARTINO, M.N.; FERIA, J.S.; ZARITZKY, N.E. Physicochemical and microstructural characterization of films prepared by thermal and cold gelatinization from non-conventional sources of starches. Carb. Polym., v.60, p.235-244, 2005.

BIALOPIOTROWICZ, T. Wettability of starch gel films. Food Hydrocoll., v.17, p.141-147, 2003.

BOATENG, J.S; MATTHEWS, K.H.; AUFFRET, A.D.; HUMPHREY, M.J.; STEVENS, H.N.; ECCLESTON, G.M. In vitro drug release studies of polymeric freezedried wafers and solvent-cast films using paracetamol as a model soluble drug. Int. J. Pharm., v.378, p.66-72, 2009.

BRITISH HERBAL PHARMACOPOEIA. London: British Herbal Medicine Association, 1996. p.29-30. 
BRITISH PHARMACOPOEA. London: Stationery Office, 2004. p.1145-1146.

DIMITROVA, Z.; DIMOV, B.; MANOLOVA, N. Antiherpes effect of Melissa officinalis L. extracts. Acta Microbiol. Bulg., v.9, p.65-72, 1993.

\section{EUROPEAN SCIENTIFIC COOPERATIVE ON} PHYTOTHERAPY. Monographs on the medicinal uses of plant drugs. Texas: American Botanical Council/ESCOP, 1996. v.1.

FAMA, L.; ROJAS, A.B.; GOYANES, S.; GERSCHENSON, L. Mechanical properties of tapioca-starch edible films containing sorbates. Food Sci. Technol.-LEB., v.38, p.631639, 2004.

FLORES, S.; FAMÁ, L.; ROJAS, A.M.; GOYANES, S.; GERSCHENSON, L. Physical properties of tapiocastarch edible films: Influence of filmmaking and potassium sorbate. Food Res. Int., v.40, p.257-265, 2007.

FREIRE, C.; PODCZECK, F.; VEIGA, F.; SOUSA, J. Starch-based coatings for colon-specific delivery. Part II: Physicochemical properties and in vitro drug release from high amylose maize starch films. Eur. J. Pharm. Biopharm., v.72, p.587-594, 2009.

GABY, A.R. Natural remedies for Herpes simplex. Altern Med. Rev., v.11, p.93-101, 2006.

GALIETTA, G.; DI GIOIA, L.; GUILBERT, S.; CUQ, B. Mechanical and thermomechanical properties of films based on whey proteins as affected by plasticizer and crosslinking agents. J. Dairy Sci., v.81, p.3123-3130, 1998.

HIGUCHI, T. Rate of release of medicaments from ointment bases containing drug in suspensions. J. Pharm. Sci., v.50, p.874-875, 1961.

JANSSON, A.; THUVANDER, F. Influence of thickness on the mechanical properties for starch films. Carb. Polym., v.56, p.499-503, 2004.

JASSIM, S.A.A.; NAJI, M.A. Novel antiviral agents: a medicinal plant perspective. J. Appl. Microbiol., v.93, p.412-427, 2003.
KANIS, L.A., GENEROSO, M.; MÉIER, M.M.; PIRES, A.T.N.; SOLDI, V. Poly(ethylene-co-methyl acrylate) membranes as rate-controlling barriers for drug delivery systems: characterization, mechanical properties and permeability. Eur. J. Pharm. Biopharm., v.60, p.383-390, 2005.

KOYTCHEV, R.; ALKEN, R.G.; DUNDAROV, S. Balm mint extract (Lo-701) for topical treatment of recurring herpes labialis. Phytomedicine, v.6, p.225-230, 1999.

KROGARS, K.; HEINAMAKI, J.; KARJALAINEN, M.; NISKANEN, A.; LESKELA, M.; YLIRUUSI, B. Enhanced stability of rubbery amylose-rich maize starch films plasticized with a combination of sorbitol and glycerol. Int. J. Pharm., v.251, p.205-208, 2003.

LAROTONDA, F.D.S.; MATSUI, K.N.; SOLDI, V.; LAURINDO, J.B. Biodegradable films made from raw and acetylated cassava starch. Braz. Arch. Biol. Techn., v.47, p.477-484, 2004.

LOPEZ, O.V.; GARCÍA, M.A.; ZARITZKY, N.E. Film forming capacity of chemically modified corn starches. Carb. Polym., v.73, p.573-581, 2008.

LU, D.R.; XIAO. C.M., XU, S.J. Starch-based completely biodegradable polymer materials. Polym. Lett., v.3, p.366375, 2009.

MALI, S.; SAKANAKA, L. S.; YAMASHITA, F.; GROSSMANN, M. V. E. Water sorption and mechanical properties of cassava starch films and their relation to plasticizing effect. Carb. Polym., v.60, p.283-289, 2005.

MICHAILOVA, V.; TITEVA, S.; KOTSILKOVA, R.; KRUSTEVA, E.; MINKOV, E. Influence of hydrogel structure on the process of water penetration and drug release from mixed hydroxypropylmethyl cellulose/ thermally pregelatinized waxy maize starch hydrophilic matrices. Int. J. Pharm., v.222, p.7-17, 2001.

NOLKEMPER, S.; REICHLING, J.; STINTZING, F.C.; CARLE, R.; SCHNITZLER, P. Antiviral effect of aqueous extracts from species of the Lamiaceae family against Herpes simplex Virus type 1 and type 2 in vitro. Planta Med., v.72, p.1-5, 2006.

PAES, S.S., YAKIMETS, I, MITCHELL, J.R. Influence of gelatinization process on functional properties of cassava starch films. Food Hydrocoll., v.22, p.788-797, 2008. 
PANCHAGNULA, R. Transdermal delivery of drugs. Indian J. Pharmacol., v.29, p.140-156, 1997.

PEPPAS, N.A. Analysis of fickian and non-fickian drug release from polymers. Pharm. Acta. Helv., v.60, p.110-111,1985.

ROBINSON, J.R.; LEE, V.H.L. Controlled drug delivery fundamentals and applications. New York: Marcel Dekker, 1987. $716 \mathrm{p}$.

SHIMAZU, A.A; MALI, S.; GROSSMANN, M.V.E. Efeito plastificante e antiplastificante do glycerol em filmes biodegradáveis de amido de mandioca. Semina Cien. Agra., v.28, p.79-88, 2007.

SOEST, V.; KNOOREN, J.N. Influence of glycerol and water content on the structure and properties of extruded starch plastic sheets during aging. J. Appl. Polym. Sci., v.64, p.1411-1422, 1997.

TALJA, R.A.; HELÉN, H.; ROOS, Y.H.; JOUPPILA, K. Effect of type and content of binary polyol mixtures on physical and mechanical properties of starch-based edible films. Carb. Polym., v.71, p.269-276, 2008.
TYLER, V. E. Herb's of choice: the therapeutic use of phytomedicinalis. New York: Hawthorne Press, 1994. 209 p.

YOON, H.S.; LEE, J.H.; LIM, S.T. Utilization of retrograded waxy maize starch gels as tablet matrix for controlled release of theophylline. Carb. Polym., v.76, p.449-453, 2009.

YU, J.H, WANG, J.L., WU, X., ZHU, P.X. Effect of glycerol on water vapor sorption and mechanical properties of starch/ clay composite films. Starch, v.60, p.257-262, 2008.

VEIGA, F.J.B. Medicamentos orais de liberação controlada. Bol. Fac. Farm. Coimbra, v.2, p.17-87, 1988.

VILA JATO, J.L. Tecnologia farmacêutica. Madrid: Editorial Sínteses, 2001. v.2, p.324.

WORLD HEALTH ORGANIZATION. List of monographs: Folium Melissae. Geneva, 2004. p. 180-187.

Received for publication on $03^{\text {rd }}$ February 2009 Accepted for publication on $10^{\text {th }}$ February 2010 